Cadman, C. H. (1959). J. gen. Microbiol. 20, 113-128

\title{
Some Properties of an Inhibitor of Virus Infection from Leaves of Raspberry
}

\author{
By C. H. CADMAN
}

Scottish Horticultural Research Institute, Invergowrie, by Dundee

SUMMARY: Raspberry leaves contain a substance which prevents the infection of plants by viruses when it is mixed with the inoculum. It is lost on dialysis, precipitated by nicotine or added protein, unaffected by boiling or freezing, and is probably a phenolic tanning agent. Extracts from peach or apple leaves contain less of such substances than do those from leaves of plum, cherry, raspberry or strawberry. The degree to which virus infection is inhibited by tanning substances from raspberry or other sources depends on the virus and not on the species of test plant. Raspberry tannin and tannic acid combine irreversibly with some viruses but with others the combination is readily reversed by dilution or increase in $\mathrm{pH}$ value. With potato ring necrosis, tobacco mosaic and tobacco necrosis viruses, there seems to be a fixed ratio between the amount of virus and the amount of tannin needed to decrease infectivity by a fixed proportion. The infectivity of extracts made from raspberry leaves containing raspberry ring spot or beet ring spot viruses varied with the concentration of tannin present and the $\mathrm{pH}$ value. The amount of virus sedimented by centrifuging such extracts at low speed decreased with increase of $\mathrm{pH}$ value. Extracts made with $2.5 \%$ nicotine in water were usually more infective than those made with alumina or phosphate buffer ( $\mathrm{pH} 8$ ), and much more infective than those made with water. Both viruses are precipitated by acetone or ammonium sulphate from extracts of infected raspberry leaves made with nicotine or alumina; beet ring spot virus was detected serologically in such preparations from infected raspberry leaves.

Viruses may be difficult or impossible to transmit from plant to plant by mechanical inoculation of sap because of the intrinsic properties of the viruses, because they are present in too small amounts or because extracts from infected leaves contain substances which prevent infection. For example, only a few viruses have been transmitted mechanically from or to rosaceous plants, and it is widely supposed that this is because their leaves contain powerful inhibitors of virus infection and that these are tannins (Bawden, 1956). Bawden \& Kleczkowski (1945) showed that leaf extracts made from raspberry and strawberry plants which were infected with aphid-borne viruses contained little or no protein and large amounts of substances, presumed to be tannins, which inhibited infection of plants by viruses and precipitated proteins. However, no attempts seem to have been made to find whether leaf extracts from other kinds of rosaceous plants behave like those from raspberry or strawberry. Much of the evidence for the occurrence of tannins in the saps of rosaceous and other plants quoted in botanical literature is based solely on chemical tests, such as the coloration of metallic salt solutions (e.g. McNair, 1930), which fail to distinguish phenolic compounds that precipitate proteins and possess tanning activity from those that do not. The latter occur in the saps of many plants, for instance tobacco (Reid, 1956), which 
have no tanning properties and little or no effect on the infectivity of virus preparations.

Tanning agents preserve and stabilize hide, converting it to leather, and it seems generally agreed that they act by linking together different parts of the polypeptide backbone of the same protein fibre and of adjacent protein fibres. Extracts from many kinds of plants possess these properties and also contain phenolic substances, many of which give the diagnostic chemical reactions of 'tannins' used by botanists, although few may actually be tanning agents. White (1957) believed that, of the phenolic substances which occur in plant extracts, only those with molecular weights in the range 500-2000 are tanning agents, and suggested that these limits are set by the need for the molecules to be large enough to have sufficient phenolic groups to cross-link adjacent collagen fibres effectively, yet small enough to diffuse between them. Hide and virus suspensions both contain proteins which react similarly with phenolic substances: the term 'tannin' is therefore used below to denote phenolic substances which possess tanning activity.

Tannins, unlike most substances present in leaf extracts which inhibit virus infection (inhibitors), seem to affect viruses directly and not the host plant (Bawden \& Kleczkowski, 1945; Hirth, 1951; Thresh, 1956). As they interfere greatly with the mechanical transmission of viruses from plants that contain them, it is surprising that little is known about their mode of action. My interest in inhibitors of this kind arose from the discovery that raspberry ring spot virus could be transmitted mechanically from raspberry to other hosts when leaves were macerated in nicotine sulphate solutions (Cadman, 1956). Experiments were therefore made to investigate the mode of action of nicotine and to get information on the nature and properties of the inhibitor or inhibitors present in raspberry sap. The results provide new evidence about the reaction between viruses and certain kinds of tannins and suggest various ways of modifying techniques of mechanical inoculation that should be useful in transmitting viruses to and from tannin-containing plants, which include raspberry, strawberry and several kinds of tree fruit plants.

\section{Methods}

Leaves from seedlings and plants of commercial varieties of raspberry (Rubus idaeus L.) were used in several ways to prepare extracts. Passing leaves through a domestic mincer, squeezing the pulp through muslin and centrifuging the juice for $3 \mathrm{~min}$. at $7000 \mathrm{~g}$ yielded a non-viscous pale yellow liquid with a highly astringent taste and $\mathrm{pH} \mathbf{5 \cdot 5}$; this is called raspberry sap. Extracts for chromatography on paper were made either by percolating columns of powdered leaf, dried in vacuo over $\mathrm{P}_{2} \mathrm{O}_{5}$, with $70 \%(\mathrm{v} / \mathrm{v})$ acetone in water (Dr A. E. Flood, personal communication); or by extracting minced fresh leaves with $50 \%(\mathrm{v} / \mathrm{v})$ acetone in water, straining the pulp through muslin and adding a large volume of ether to the preparation after clarifying it by centrifugation. Chromatograms were run at room temperature in the solvents stated. Phenolic substances were usually detected by developing the papers in the ferric chloride + ferricyanide reagent of White, Kirby \& Knowles (1952). 
For all tests made with leaves taken from raspberry or strawberry plants which were infected with mechanically-transmissible viruses, and with leaves from other rosaceous plants, weighed amounts of leaf, usually $0.5 \mathrm{~g}$., were macerated in a measured volume of liquid (usually $2.5 \mathrm{ml}$.) by using a pestle and mortar. When alumina (aluminium oxide, for chromatographic purposes, British Drug Houses, Ltd.) or carborundum were used, weighed amounts were sprinkled over the leaves before they were macerated. The liquids mixed with the leaves were distilled water, buffer solutions or $2.5 \%(\mathrm{v} / \mathrm{v})$ commercial nicotine in water (basic alkaloid; 98/99\% distilled nicotine, Murphy Chemical Co.; nicotine sulphate was never used). The preparations made by macerating the leaves were usually further diluted with water before mixing with virus suspensions or inoculating to test plants. For convenience, extracts made with water, alumina or nicotine solution are called water, alumina or nicotine extracts, respectively.

The sources of raspberry ring spot virus (Cadman, 1956) were either fresh sap from systemically infected leaves of Nicotiana rustica L., Malling Jewel raspberry or Fragaria vesca L. plants; $\boldsymbol{F}$. vesca was infected by grafting with shoots from diseased Malling Promise raspberry (Mr R. M. Lister, private communication). Leaves from naturally infected plants of Malling Seedling V raspberry or frozen sap from infected White Burley tobacco plants, were the sources of the beet ring spot strain of tomato black ring virus (Harrison, 1957, 1959). The Rothamsted culture of tobacco necrosis virus, turnip crinkle virus and potato ring necrosis virus (PRN virus ; Cadman, 1958), which is a strain of potato stemmottle virus, were cultured in French bean, turnip and tobacco, respectively, and the infective saps stored frozen. Most work was done with PRN virus because infection by it was more readily inhibited by tanning agents than was that of the other viruses. Lucerne mosaic virus, and potato viruses $X$ and $Y$ were used as fresh sap from systemically infected leaves of Petunia hybrida Vilm. or Nicotiana glutinosa L. Tests with tobacco mosaic virus were made with a preparation from systemically infected White Burley tobacco leaves purified by successive precipitations with ammonium sulphate and at $\mathrm{pH} \mathbf{3} \cdot \mathbf{2}$.

The infectivity of different preparations was compared by inoculation to hosts in which countable local lesions were produced. Infectivity tests, using extracts from leaves of raspberry and other plants, tannic acid (British Drug Houses, Ltd.) and other substances, were usually made by mixing preparations with virus suspensions immediately before inoculation. Infectivity of preparations of raspberry ring spot virus, beet ring spot virus, turnip crinkle virus and potato viruses $X$ and $Y$ was tested in Chenopodium amaranticolor Coste \& Reyn., that of PRN virus and tobacco necrosis virus in French bean (Phaseolus vulgaris L., var. Prince), Nicotiana glutinosa and C. amaranticolor, and that of lucerne mosaic virus in French bean. The preparations compared were inoculated to equal numbers of whole or half-leaves randomly distributed among the test plants used; at least six whole leaves of $C$. amaranticolor, six half-leaves of $N$. glutinosa and eight half-leaves of French bean were inoculated with each preparation. To increase the numbers of infections, 'Super-floss Celite' (Johns-Manville Ltd.), an abrasive, was usually mixed 
with the inoculum, which was applied with the forefinger. Leaves were not rinsed after inoculation. The antiserum to beet ring spot virus used in the serological tests was the one described by Harrison (1957).

\section{RESULTS}

\section{Properties and nature of the inhibitor from raspberry leaves}

Preliminary work showed that sap from roots and leaves of raspberry inhibited infection of French bean by tobacco necrosis virus, that leaf sap was usually more inhibitory than root sap and that its activity varied greatly. Sap from leaves sampled in summer and autumn was more inhibitory than sap from leaves sampled in spring and sap from plants grown under glass in winter contained little or no inhibitor unless the raspberry plants had been exposed for several days to light from mercury vapour lamps.

Tests made with PRN virus in French bean showed that boiling for $10 \mathrm{~min}$. or freezing for $24 \mathrm{hr}$. had little effect on the inhibitory activity of raspberry sap or leaf extracts (Expt. 1, Table 1). However, leaf extracts made in the presence of nicotine or alumina, and water extracts mixed with an equal volume of healthy tobacco sap or dialysed overnight against tap water had little or no inhibitory activity (Expts. 2 and 4). Similar results were obtained when tobacco mosaic or tobacco necrosis viruses were used instead of PRN virus. Water extracts of raspberry leaves, either freshly prepared or kept frozen or chilled for $48 \mathrm{hr}$., precipitated the proteins in normal rabbit serum, showing that such preparations cannot be used in serological tests for viruses. However, no precipitates formed when normal serum was mixed at a range of dilutions with freshly prepared extracts made with the aid of alumina or nicotine. The $\mathrm{pH}$ value of the extracts was not adjusted before mixing with serum and varied from $\mathbf{5 \cdot 5}$ (water extracts) to $\mathbf{7 \cdot 5}$ (alumina) and 9 (nicotine). Although the properties of the inhibitor in raspberry leaf extracts suggest that it may be a phenolic substance, they are not peculiar to phenolic substances; stronger evidence is provided by work with acetone extracts of leaves.

Extracts, made by percolating columns of vacuum-dried leaves with $\mathbf{7 0} \%$ $(\mathrm{v} / \mathrm{v})$ acetone in water, inhibited infection of French bean by tobacco necrosis virus more powerfully than those made by grinding an equivalent amount of fresh leaf in water. Preliminary work, using paper chromatography and the counter-current distribution technique (Craig, 1944), showed that acetone extracts contained a number of phenolic substances and that inhibitory activity was associated with that part of the extracts which was insoluble in ether. When nine volumes of ether were added to clarified extracts of fresh leaves, made by mixing minced leaves with twice their weight of $50 \%(\mathrm{v} / \mathrm{v})$ acetone in water, straining the liquid through muslin and centrifuging, material insoluble in ether collected in the aqueous phase of the mixture and could be separated off. The ether and acetone were removed by evaporation under reduced pressure, leaving a clear brown liquid. A cream-coloured sediment, insoluble in water, formed when this liquid was kept for a few hours at room temperature or at $5^{\circ}$. The amount of sediment increased with time and the 
liquid slowly lost its inhibitory activity. One preparation which, at $1 / 1000$, inhibited PRN virus strongly when first made, had lost $90 \%$ of its inhibitory activity when tested $\mathbf{5}$ months later, but it still weakly inhibited infection by tobacco mosaic and tobacco necrosis viruses and precipitated normal serum.

Table 1. Inhibition of potato ring necrosis virus by raspberry sap and leaf extracts

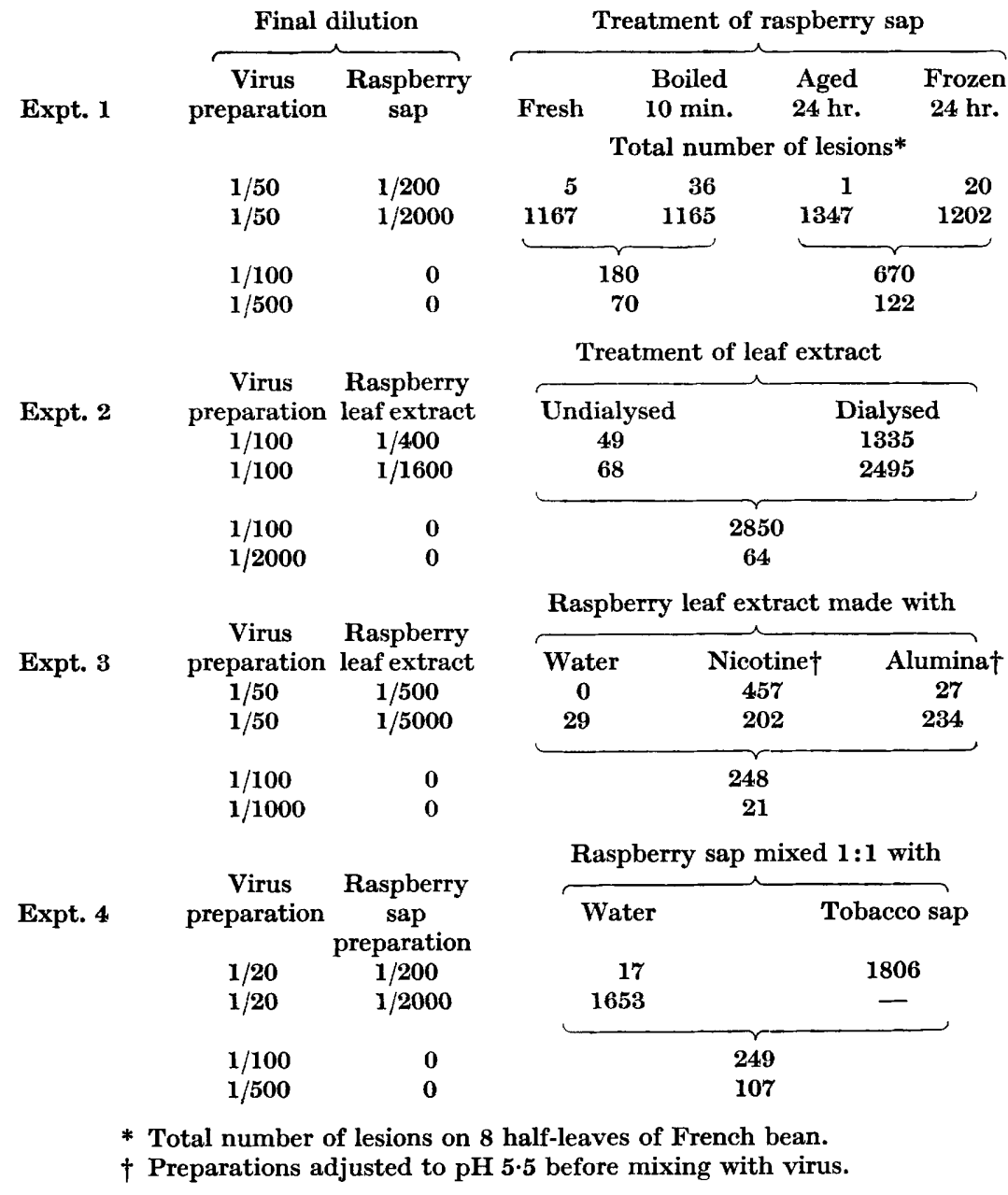

Paper chromatography showed that the ether-insoluble fraction contained a number of phenolic substances. The major constituent, however, was one which streaked in $\mathrm{N}$-acetic acid and was immobile in butan-1-ol: acetic acid : water $(6: 1: 2)$ mixture and in water-saturated butan-2-ol. This substance fluoresced a dull violet in ultraviolet light when the paper was exposed to ammonia vapour, and it coloured ferric salts mauve. This substance is almost certainly a tannin butits identity is unknown. Tests made by DrD. E. Hathway (personal communication) showed that it did not contain phloroglucinol groups. 
When $0.6 \mathrm{ml}$. samples of the ether-insoluble fraction were applied, as a band of $20 \mu \mathrm{l}$. spots to $25 \times 30 \mathrm{~cm}$. sheets of Whatman $3 \mathrm{MM}$ paper and the sheets run in distilled water, phenolic materials separated into three bands with $R_{F}$-values of approximately $0,0 \cdot 5-0 \cdot 6$ and $0 \cdot 7-0 \cdot 8$, respectively. The sheets were subsequently dried, cut transversely into strips $2 \mathrm{~cm}$. wide and these soaked overnight in $3 \mathrm{ml}$. phosphate buffer $(\mathrm{pH} 7)$. The eluates, adjusted to pH 5.5 with $0 \cdot 1 \mathrm{~N}-\mathrm{HCl}$, were mixed with samples of PRN virus preparations already diluted 1/250 with water, and the mixtures inoculated to French bean leaves. In two tests of this kind, the eluate from the strip which included the bulk of the phenolic material with zero $R_{F}$ value decreased infectivity to 20-25\% that of control virus preparations diluted with water and adjusted to pH 5.5, a degree of inhibition comparable to that caused by the original extract diluted $10^{-3}$ or by a solution containing $0 \cdot 25 \mu \mathrm{g}$. tannic acid $/ \mathrm{ml}$. The phenolic material which had an $R_{F}$ value of zero in organic solvents was probably eluted from the paper in these experiments, but no tests were made to confirm this. Eluates from the band with $\boldsymbol{R}_{\boldsymbol{F}} \mathbf{0} \cdot \mathbf{6}-\mathbf{0} \cdot \mathbf{7}$ decreased the infectivity of PRN virus slightly, but those from all other portions of the chromatogram had no such effect.

Although the results do not exclude the existence of other kinds of inhibitors, they suggest that the inhibitory properties of raspberry leaf extracts are associated with one or more phenolic substances. The major phenolic constituent of preparations made from raspberry leaves is probably a tannin which is present in amounts adequate to account for the inhibitory effects observed. The results of comparative tests with tannic acid and raspherry leaf extract suggest that raspberry leaves contain the equivalent of 10-100 mg. tannic acid/g. fresh leaf. However, complex phenolic substances often rapidly undergo chemical changes during isolation from plant tissue, and it is not certain that the inhibitor present in raspberry leaves is identical with the tannin in extracts made from them.

As it is so often stated that the leaves of all rosaceous plants contain tannins, it is interesting to compare the behaviour of raspberry leaf extracts with those from related plants. The results of tests with PRN virus (Table 2) show that peach and apple leaf extracts inhibited infection much less than those from raspberry, strawberry, plum and cherry.

\section{Mode of inhibition of virus infection by tannins}

Bawden \& Kleczkowski (1945) and Thresh (1956) inferred that raspberry and strawberry leaf extracts inhibited infection of plants by viruses by acting directly on the viruses rather than on the host plants, and they implied that all tannins might behave in this way. Thresh likened the reaction between viruses and tannins to that between hide proteins and tannins, and suggested that viruses form non-infective complexes with tannins, from which infective virus is released when the complexes are dissociated by dilution or increase of $\mathrm{pH}$ value. My results support these ideas but they also show the need for caution in making generalizations.

The best evidence that raspberry tannin and tannic acid act directly on 


\section{Table 2. Inhibition of infection of French bean by potato ring necrosis} virus by water extracts from leaves of rosaceous plants

1 vol. of leaf extract was mixed with 1 vol. of virus preparation already diluted 1/50 with water and the dilution factor equivalent to the degree of inhibition observed estimated from dilution curves for PRN virus in water plotted for each experiment.

$\begin{array}{lcc}\text { Final dilution } & \begin{array}{c}\text { Dilution factor } \\ \text { equivalent to } \\ \text { degree of } \\ \text { inhibition } \\ \text { observed } \\ \text { of leaf extract }\end{array} & 1 / 2 \cdot 7 \\ \text { Peach } & 1 / 20 & 1 / 5 \cdot 6 \\ \text { Apple } & 1 / 20 & 1 / 3 \cdot 7 \\ \text { Raspberry } & 1 / 1000 & 1 / 2 \cdot 1 \\ \text { Fragaria vesca } & 1 / 100,000 & 1 / 10 \\ \text { Cherry } & >1 / 100,000 & 1 / 10 \\ \text { Plum } & >1 / 100,000 & \end{array}$

viruses is the fact that the degree of inhibition depends on the virus but not on the host plant (Tables 3 and 4). The figures in column 4, Table 3, were obtained by plotting dilution curves for the different viruses and estimating from these the dilution in water needed to decrease infectivity to the same extent as did the added inhibitor. Infection with PRN virus was strongly inhibited by preparations of inhibitor diluted until they were without effects on infection by the other viruses. Infection of French bean by PRN virus or tobacco necrosis virus was not inhibited by spraying the lower surfaces of leaves with $4 \%$ tannic acid solution at intervals before or after inoculation, by rubbing inoculated surfaces of leaves with tannic acid solution, $50 \mu \mathrm{g} . / \mathrm{ml}$., $30 \mathrm{~min}$. or more after inoculation nor by mixing non-tanning phenolics in the

Table 3. Inhibition of infection by different viruses caused by raspberry sap or tannic acid

\begin{tabular}{|c|c|c|c|c|}
\hline \multirow[b]{2}{*}{ Virus } & \multicolumn{2}{|c|}{ Final dilution } & \multirow{2}{*}{$\begin{array}{c}\text { Dilution } \\
\text { factor } \\
\text { equivalent to } \\
\text { degree of } \\
\text { inhibition } \\
\text { observed }\end{array}$} & \multirow[b]{2}{*}{ Test plant } \\
\hline & $\begin{array}{l}\text { Virus } \\
\text { preparation }\end{array}$ & $\begin{array}{c}\text { Raspberry } \\
\text { sap }\end{array}$ & & \\
\hline Tobacco necrosis & $1 / 5000$ & $1 / 5$ & $1 / 7 \cdot 4)$ & \\
\hline Lucerne mosaic & $1 / 50$ & $1 / 50$ & $1 / 5 \cdot 5\}$ & French bean \\
\hline $\begin{array}{c}\text { Potato ring } \\
\text { necrosis }\end{array}$ & $1 / 50$ & $1 / 1000$ & $1 / 8 \cdot 1$ & \\
\hline $\begin{array}{l}\text { Raspberry ring } \\
\text { spot }\end{array}$ & $1 / 25$ & $1 / 5$ & $1 / 8 \cdot 0)$ & $\begin{array}{l}\text { Chenopodium } \\
\text { amaranticolor }\end{array}$ \\
\hline \multirow[t]{2}{*}{ Turnip crinkle } & $1 / 20$ & $1 / 5$ & $1 / 6 \cdot 3$ & \\
\hline & $\begin{array}{c}\text { Virus } \\
\text { preparation }\end{array}$ & $\begin{array}{c}\text { Tannic acid } \\
(\mu \mathrm{g} . / \mathrm{ml} .)\end{array}$ & & \\
\hline Tobacco necrosis & $1 / 30,000$ & 500 & $1 / 6 \cdot 3$ & \\
\hline Tobacco necrosis & $1 / 30,000$ & 100 & $1 / 2 \cdot 0$ & \\
\hline $\begin{array}{l}\text { Potato ring } \\
\text { necrosis }\end{array}$ & $1 / 100$ & 2 & $1 / 4 \cdot 6$ & French bean \\
\hline $\begin{array}{l}\text { Potato ring } \\
\text { necrosis }\end{array}$ & $1 / 100$ & 0.5 & $1 / 1 \cdot 3$ & \\
\hline
\end{tabular}


inoculum. The non-tanning phenolics included quercitrin, D-catechin, chlorogenic, cinnamic, gallic and protocatechuic acids and a leucoanthocyanin from cocoa (kindly supplied by Dr T. Swain) and were used at concentrations of $1 \mathrm{mg} . / \mathrm{ml}$.

Table 4. Inhibition of infection of different hosts by potato ring necrosis virus caused by water extracts of raspberry leaves

\begin{tabular}{|c|c|c|c|c|}
\hline \multicolumn{2}{|c|}{ Final dilution } & \multicolumn{3}{|c|}{ Test plant } \\
\hline \multirow[t]{2}{*}{$\begin{array}{c}\text { Virus } \\
\text { preparation }\end{array}$} & $\begin{array}{c}\text { Raspberry } \\
\text { leaf extract }\end{array}$ & $\begin{array}{l}\text { Nicotiana } \\
\text { glutinosa* }\end{array}$ & $\begin{array}{l}\text { Chenopodium } \dagger \\
\text { amaranticolor }\end{array}$ & $\begin{array}{c}\text { French } \\
\text { bean }\end{array}$ \\
\hline & & \multicolumn{3}{|c|}{ Total number of lesions } \\
\hline $1 / 20$ & $1 / 50$ & 2 & 5 & 6 \\
\hline $1 / 20$ & $1 / 500$ & 386 & 65 & 47 \\
\hline $1 / 20$ & 0 & 759 & 136 & 294 \\
\hline $1 / 100$ & $\mathbf{0}$ & 305 & 66 & 43 \\
\hline \multicolumn{5}{|c|}{$\begin{array}{l}\text { Celite mixed in the inoculum. } \\
\text { No Celite in the inoculum. } \\
\text { Figures are total lesions in } 6 \text { half-leaves of } N . \text { glutinosa, } 6 \text { whole leaves } C \text {. amaranticolor } \\
8 \text { half-leaves of French bean. }\end{array}$} \\
\hline
\end{tabular}

Thresh (1956) showed that when tannic acid at a concentration sufficient to abolish infectivity was mixed with tobacco mosaic virus, the precipitate produced contained nearly all the virus: infectivity was fully restored by resuspending the precipitate in a volume of water equal to that of the untreated preparations. He obtained similar results when a tobacco necrosis virus from strawberry was mixed with raspberry or strawberry leaf sap, and he showed that the infectivity of non-infective mixtures of viruses and inhibitors was restored when these were diluted with water. My results from similar experiments with potato viruses $X$ and $Y$, tobacco mosaic, tobacco necrosis, turnip crinkle and raspberry ring spot viruses confirm and extend his results, except that tobacco necrosis virus was only partially precipitated by concentrations of tannic acid or raspberry leaf extract which completely precipitated the other viruses. Inhibitor was readily detected in the resuspended precipitates from mixtures of tobacco mosaic with tannic acid or raspberry tannin, showing that the non-infective precipitates are mixtures of virus and inhibitor. Precipitates were also produced when raspberry sap or leaf extracts or tannic acid were added in varying amounts to clarified sap from tobacco plants infected with PRN virus, but no virus was detected in the resuspended precipitates; nor was the infectivity of non-infective mixtures of virus and inhibitor restored by dilution. Similar results were obtained when raspberry sap was mixed with sap from Petunia hybrida plants infected with lucerne mosaic virus.

The effects of other kinds of inhibitors which precipitate viruses, such as ribonuclease or the glycoprotein from Phytolacca esculenta, are also abolished by dilution, but the infectivity of mixtures of virus and inhibitor bears little relation to the proportion of the constituents (Kassanis \& Kleczkowski, 1948).

The infectivity of mixtures of PRN virus with raspberry leaf extract, or of tobacco mosaic or tobacco necrosis viruses or PRN virus with tannic acid, 
however, depends on the ratio of virus to inhibitor. The results in Table 5 show that the concentration of tannic acid needed to decrease the infectivity of preparations of PRN virus by an amount equivalent to a 1/20 dilution with water was proportional to the virus concentration. After centrifugation for 2 min. at $7,000 \mathrm{~g}$, the supernatant fluid from mixtures of PRN virus with tannic acid was less infective than comparable uncentrifuged mixtures, but the amount of the decrease seemed independent of the concentrations of the reactants. Similar results were obtained when tobacco mosaic or tobacco necrosis viruses were used instead of PRN virus, but both these viruses are relatively insensitive to tannic acid: at least $500 \mu \mathrm{g} . / \mathrm{ml}$. was needed to halve the infectivity of preparations containing $100 \mu \mathrm{g} . / \mathrm{ml}$. tobacco mosaic virus.

Table 5. Amount of tannic acid needed to prevent infection of French bean by different amounts of potato ring necrosis virus

1 vol. of tannic acid solution was mixed with 1 vol. of virus preparation.

$\begin{array}{ccc} & \begin{array}{c}\text { Concentration of } \\ \text { tannic acid needed } \\ \text { to decrease infectivity } \\ \text { by an amount }\end{array} & \\ \text { Virus content of } & \begin{array}{c}\text { equivalent to a } \\ \text { dilution of } 1 / 20\end{array} & \begin{array}{c}\text { Ratio } \\ \text { virus } / \text { tannic }\end{array} \\ \text { (arbitrary units) } & \text { with water }(\mu \mathrm{g} . / \mathrm{ml} \text { ) } & \text { acid } \\ 250 & 47 \cdot 2 & 5 \cdot 3 \\ 50 & 8 \cdot 9 & 5 \cdot 6 \\ 10 & 1 \cdot 5 & 6 \cdot 7\end{array}$

Tannic acid and raspberry tannin also differ from most other kinds of inhibitors in that their effects increase with increase of time between mixing with viruses and inoculating the mixtures to test plants. In one experiment with PRN virus, virus preparations mixed with $5 \mu \mathrm{g}$. tannic acid/ml. 48, 24 and $0 \mathrm{hr}$. before inoculation to French bean, produced, 35, 92 and 123 lesions, respectively, compared with 909 and 206 produced by untreated virus preparations at the same dilution and at $1 / 4$, of the others, respectively. Thornberry (1935) obtained striking evidence of the delayed reaction of tannic acid with tobacco mosaic virus and showed that the degree of inhibition depends on the $\mathrm{pH}$ value; concentrations of tannic acid which abolished or greatly decreased infectivity when mixed with tobacco mosaic virus at $\mathrm{pH} 4.5$ had little or no effect when mixed with virus at $\mathrm{pH} 7-8$. I have noticed that the optical properties of mixtures of tobacco mosaic virus and tannic acid also vary with the $\mathrm{pH}$ value of the mixture. Those containing virus and tannin in proportions less than $2: 1$ showed no anisotropy of flow when viewed in polarized light but this property was regained by mixtures containing $100 \mu \mathrm{g}$.virus/ ml. or more, when the $\mathrm{pH}$ value was raised to 7. Anisotropy of flow was gradually lost when the $\mathrm{pH}$ value of mixtures in which the ratio was more than 2:1 was lowered to $\mathrm{pH} 4 \cdot 0$ : those mixtures that contained more than $2 \mathrm{mg}$. virus/ml. set spontaneously to birefringent gels. Mixing PRN virus and tannic acid at $\mathrm{pH} 8 \cdot 0$ decreased but did not abolish the inhibitory effect of the latter. 
The results described above strongly suggest that when raspberry sap or tannic acid are used at concentrations which do not injure inoculated leaves, they inhibit infection of plants by viruses through direct action on the viruses.

\section{Factors affecting the mechanical transmission of viruses from raspberry}

Plants of Malling Jewel raspberry infected with raspberry ring spot virus and plants of Malling Seedling $\mathrm{V}$ infected with beet ring spot virus offered convenient systems for testing the methods for transmitting viruses from tannin-containing plants suggested by the results obtained with in vitro mixtures. Maceration of infected leaves of Malling Jewel raspberry in 10 to 20 times their weight of water diluted the tannin sufficiently to give preparations which infected Chenopodium amaranticolor, Petunia hybrida, tobacco and Nicotiana rustica. However, maceration of the leaves in buffer solutions of $\mathrm{pH}$ 6-8 gave preparations which were much more infective. The results in

\section{Table 6. The effect of $p H$ on the infectivity of extracts made from leaves} of Malling Jewel raspberry infected with raspberry ring spot virus

The inocula were prepared by macerating $0.5 \mathrm{~g}$. infected leaf tissue in $2.5 \mathrm{ml} .0 .05 \mathrm{M}$ phosphate buffer of the specified $\mathrm{pH}$, centrifuging and re-suspending the precipitates in volumes of buffer solution equal to and of the same $\mathrm{pH}$ as those of the supernatant fluid.

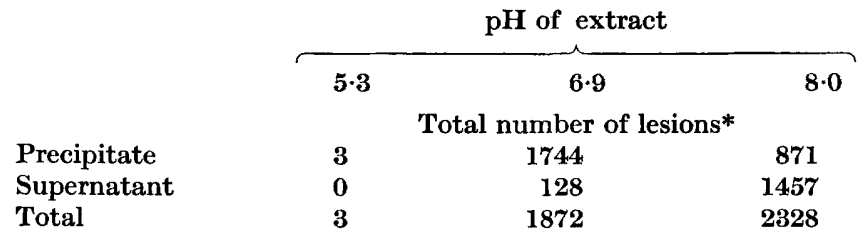

* Total number of lesions that developed in 6 whole leaves of Chenopodium amaranticolor inoculated with the preparations diluted 1/20 and mixed with Celite.

Table 6 are typical of many and were obtained by macerating infected raspberry leaves in $0.05 \mathrm{M}$-phosphate buffer of the specified $\mathrm{pH}$. Raspberry sap is acid, and drops of $0 \cdot 1 \mathrm{~N}-\mathrm{NaOH}$ had to be added at intervals to maintain the desired $\mathrm{pH}$ value. All the preparations were made up to the same volume with water and then centrifuged at $7000 \mathrm{~g}$ for $3 \mathrm{~min}$. The precipitates were suspended in volumes of buffer equal to those of the supernatant fluids and the $\mathrm{pH}$ values re-adjusted where necessary. Infectivity was much less at $\mathrm{pH} \mathbf{5 \cdot 3}$ than at 6.9 ; preparations made at $\mathrm{pH} 6.9$ and $8 \cdot 0$ had similar total infectivities but more of the virus was present in the supernatant fluid at $\mathrm{pH} 8 \cdot 0$ than at 6.9. Infectivity also increased when the resuspended precipitate and the supernatant fluid at $\mathrm{pH} 5 \cdot 3$ were adjusted to $\mathrm{pH} 8 \cdot 0$; indeed the total infectivity

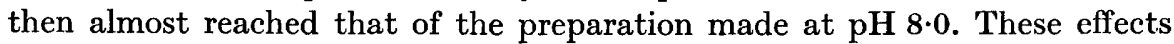
were independent of the ionic constitution of the buffer solutions and extracts made at $\mathrm{pH} 8$ with dilute $\mathrm{NaOH}$ were as infective as those made with buffer. Extracts made with neutral phosphate buffer lost much of their infectivity when dialysed overnight against tap water but little or none when dialysed against neutral buffer; comparable preparations made with water lost more of 
their infectivity than those prepared with buffer when allowed to stand overnight at room temperature and also lost more infectivity when dialysed against water than against buffer.

Extracts made with $\mathbf{2 . 5} \%$ nicotine solution adjusted to $\mathrm{pH} 8$ with $\mathrm{N}-\mathrm{HCl}$ were usually more infective than those made with either alumina or phosphate buffer at the same $\mathrm{pH}$ value. The ratio of alumina to infected raspberry leaf seemed critical when preparations were made with water but not when made

Table 7. The effect of alumina and nicotine at different $p H$ values on the infectivity of extracts made from Malling Jewel raspberry leaves infected with raspberry ring spot virus

The inocula were prepared by macerating $0.5 \mathrm{~g}$. infected leaf in $2.5 \mathrm{ml} .0 .05 \mathrm{M}$ phosphate buffer solution, $2.5 \%$ nicotine or water plus alumina readjusted to the correct $\mathrm{pH}$ with $\mathrm{HCl}$ or $\mathrm{NaOH}$ where necessary. The preparations were centrifuged and the precipitates resuspended in a volume of buffer equal to and of the same $\mathrm{pH}$ as the supernatant fluid.

\begin{tabular}{|c|c|c|c|c|c|}
\hline & & \multicolumn{2}{|c|}{ Expt. 1} & \multicolumn{2}{|c|}{ Expt. 2} \\
\hline & & Alumina $+\mathbf{H C l}$ & Buffer & Nicotine $+\mathbf{H C l}$ & Buffer \\
\hline & & Total number & lesions* & Total numbe & lesions* \\
\hline \multirow{5}{*}{ pH 5.3 } & (Precipitate & 18 & 6 & 54 & 63 \\
\hline & Supernatant & 9 & 9 & 0 & 17 \\
\hline & (Total & 27 & 15 & 54 & 80 \\
\hline & & \multicolumn{2}{|c|}{ Expt. 3} & \multicolumn{2}{|c|}{ Expt. 4} \\
\hline & & Alumina $+\mathrm{NaOH}$ & Buffer & Nicotine $+\mathbf{H C l}$ & Buffer \\
\hline \multirow{3}{*}{ pH 8.0 } & Precipitate & 58 & 194 & 296 & 416 \\
\hline & Supernatant & 1250 & 622 & 2796 & 934 \\
\hline & Total & 1308 & 816 & 3092 & 1350 \\
\hline
\end{tabular}

* Total number of lesions that developed in 6 whole leaves of Chenopodium amaranticolor inoculated with the preparations diluted $1 / 20$ and mixed with Celite.

with pH 8 phosphate buffer. Equal weights of alumina and leaf gave more infective preparations and more of the virus was present in the supernatant fluid than when the ratio was 1:5; with increasing amounts of alumina the $\mathrm{pH}$ value of preparations made with water increased from $5 \cdot 3$ to $7 \cdot 5$. The abrasive action of alumina seems unimportant, for comparable preparations made with water and equal weights of carborundum or alumina produced 11 and 1735 lesions in six inoculated leaves of Chenopodium amaranticolor, respectively. Neither alumina nor nicotine increased the infectivity of extracts from raspberry leaves infected with raspberry ring spot virus made and held at pH 5.3 (Table 7 ), and at the concentrations tested ( $1 \%$ ) neither cinchonine, which is soluble only in acid solutions, nor colchicine at either $\mathrm{pH} 5$ or 10, increased the infectivity of extracts from infected raspberry leaves. Solutions of nicotine sulphate, which are neutral and decrease in $\mathrm{pH}$ value when mixed with acid leaf material, do not behave like nicotine (Mr R. M. Lister, private communication).

The infectivity of extracts made with the aid of alumina or nicotine from raspberry leaves containing raspberry ring spot virus varied little during the 
growing season, and raspberry yellow dwarf virus (Harrison, 1958) was readily transmitted mechanically from senescent infected leaves of Malling Exploit raspberry collected in October.

Concentrations of nicotine and alumina which increased the infectivity of raspberry sap also increased the infectivity of extracts of Fragaria vesca leaves containing raspberry ring spot virus. When $0.5 \mathrm{~g}$. leaf was ground in $5 \mathrm{ml}$. of water, pH 8 phosphate buffer, $2.5 \%$ nicotine solution or with $0.1 \mathrm{~N}$ $\mathrm{NaOH}+0.5 \mathrm{~g}$. alumina, the preparations diluted 1/50 with water and inoculated to six leaves of $C$. amaranticolor produced 14, 361, 1642 and 1410 lesions, respectively.

Harrison (1957) found that beet ring spot virus was precipitated from clarified infective tobacco sap, with little loss of infectivity, by acetone or ammonium sulphate. Both beet ring spot and raspberry ring spot viruses were precipitated when extracts of infected raspberry leaves made at $\mathrm{pH} 8$ with either alumina or nicotine, were mixed with an equal volume of acetone or one half volume of saturated ammonium sulphate solution adjusted to $\mathrm{pH} 7$ with dilute $\mathrm{NaOH}$. Although most of the precipitate did not dissolve in neutral phosphate buffer or water, most of the virus did (Table 8). The most infective preparations were usually made by acetone precipitation from nicotine extracts. That nicotine is more effective than alumina in the extraction procedure is also indicated by the presence of material which inhibited PRN virus in alumina extracts but not in nicotine extracts.

Table 8. Precipitation of beet ring spot and raspberry ring spot viruses from extracts of infected raspberry leaves

The inocula were prepared by macerating $1 \mathrm{~g}$. infected leaf in $5 \mathrm{ml} .2 .5 \%$ nicotine or water made alkaline with dilute $\mathrm{NaOH}$ and $1 \mathrm{~g}$. alumina. The ammonium sulphate was adjusted to $\mathrm{pH} 7$ with $\mathrm{NaOH}$ and the precipitates produced by this and acetone were resuspended in water. All preparations were tested at equivalent dilutions.

\begin{tabular}{|c|c|c|c|c|c|}
\hline \multirow{3}{*}{$\begin{array}{c}\text { Precipitating } \\
\text { agent }\end{array}$} & \multirow[b]{2}{*}{$\begin{array}{c}\text { Final dilution } \\
\text { of sample }\end{array}$} & \multicolumn{2}{|c|}{ Raspberry ring spot virus } & \multicolumn{2}{|c|}{ Beet ring spot virus } \\
\hline & & $\begin{array}{c}\text { Alumina } \\
\text { extract }\end{array}$ & $\begin{array}{l}\text { Nicotine } \\
\text { extract }\end{array}$ & $\begin{array}{c}\text { Alumina } \\
\text { extract }\end{array}$ & $\begin{array}{c}\text { Nicotine } \\
\text { extract }\end{array}$ \\
\hline & & \multicolumn{4}{|c|}{ Total number of lesions* } \\
\hline- & $1 / 20$ & 880 & 463 & 1851 & 3505 \\
\hline- & $1 / 100$ & 167 & 273 & 550 & 469 \\
\hline acetone $\dagger$ & $1 / 20$ & 910 & 2061 & 912 & 2254 \\
\hline $\begin{array}{c}\text { ammonium } \\
\text { sulphate } \$\end{array}$ & $1 / 20$ & 894 & 409 & 195 & 1620 \\
\hline
\end{tabular}

The infectivity of tannin-free preparations from raspberry leaves infected with beet ring spot virus compared favourably with that of sap from infected tobacco plants; attempts were therefore made to detect the virus serologically in the raspberry extracts. A preliminary test showed that the virus could be detected serologically after precipitation with acetone from mixtures of in- 
fective tobacco sap and leaf extract from healthy raspberry. No precipitation occurred when the preparation was incubated with normal serum or saline. The results of experiments with infective raspberry leaf extracts were disappointing, however. In one of these, $10 \mathrm{~g}$. leaves, from infected plants of Malling Seedling V were macerated in $25 \mathrm{ml}$. of $2.5 \%$ nicotine solution, the liquid strained through muslin, clarified by centrifugation and mixed with an equal volume of acetone. The precipitate produced was resuspended in one-fifth of the original volume of water and centrifuged again. This preparation was almost as infective as the nicotine extract and it precipitated specifically with antiserum to beet ring spot virus, although the precipitation end-point with antiserum diluted $1 / 30$ was only $1 / 1$ after $5 \mathrm{hr}$. incubation at $36^{\circ}$. Infected raspberry leaves may contain less virus than tobacco leaves, or precipitation may be inhibited by other constituents of the preparation from raspberry, which contained little or no detectable tannin but smelt of nicotine. Further work is needed to find whether the technique used can be improved, but the present results show that beet ring spot virus can be detected by serological methods in raspberry leaf extracts.

Both beet ring spot and raspberry ring spot viruses are soil-borne (Harrison, 1956, 1957), have no known aerial vectors and can be transmitted by mechanical inoculation to a great variety of plants other than raspberry. Many attempts were made to transmit aphid-borne raspberry viruses to herbaceous hosts by the techniques described above, but all failed.

\section{DISCUSSION}

Many different kinds of substances which inhibit the infection of plants by viruses combine reversibly with and precipitate the viruses, but with most this combination seems irrelevant to their action as inhibitors. As the potency of such inhibitors seems to depend considerably on the identity of the host plant and to be independent of the virus, the ratio of virus to inhibitor in the inoculum and the time of exposure of virus to inhibitor, they are thought to act by altering the susceptibility of the host plant to infection and not by affecting the virus directly. Clearly, neither raspberry tannin nor tannic acid behave in this way. Their effects are independent of the host but depend on the virus; combination between tannin and virus seems always associated with loss of infectivity, and both effects are reversible with some viruses but irreversible with others. There is a fixed ratio between the amount of virus and the amount of tannin required for neutralization of a fixed proportion of infectivity and the degree of inhibition increases with time of exposure of virus to tannin. Both substances therefore seem to inhibit by acting directly on the virus. Further work on the nature of the reaction is needed, but it seems likely that both tannic acid and raspberry tannin act by clumping together the virus particles into complexes which have little or no infectivity. That the infectivity of supernatant fluids from centrifuged mixtures of tannic acid with PRN, tobacco mosaic or tobacco necrosis viruses, was always less than that of comparable uncentrifuged mixtures, suggests that infectious particles may become 
trapped in the sedimentable virus + tannin aggregates. The failure of some simple phenolic substances to precipitate or to inhibit tobacco necrosis virus suggests that ability to agglutinate virus particles, like ability to stabilize hide, may be a function of the size and molecular structure of the phenolic compounds.

The common usage of the term tannin implies a degree of uniformity in properties and behaviour among tanning agents for which there is little justification and it would be rash to conclude that all tannins react with viruses in the same way as do raspberry tannin and tannic acid.The phenolic tannins which occur in plant extracts fall into two main categories: (i) hydrolysable tannins, such as the gallotannin of tannic acid, which are essentially esters of glucose with gallic and related phenolic acids (White, 1957); (ii) condensed tannins many of which are quinone polymerized phenolics (Hathway, $1958 a, b)$. It seems agreed that both kinds of tannin form electrovalent linkages with the basic groups and co-ordinate linkages with the peptide groups of hide proteins, and that the relative importance of these varies both with the nature of the tannin and the length of exposure of hide to tannin (Gustavson, 1949; White, 1956). Both kinds of linkage are sensitive to $\mathrm{pH}$ but electrovalent links tend to dissociate more readily than co-ordinate ones at $\mathrm{pH} 7$. If the kind of union between viruses and tannins varies to a like degree, then the prospects of preparing infective extracts from tannin-containing plants may depend as much on the nature of the tannin as on the nature, and probably the concentration, of the viruses in such plants. However, many viruses may prove transmissible by mechanical inoculation of sap from tannin-containing plants when leaf extracts which contain relatively little tannin or which are prepared under conditions which prevent the union of tannin with virus are used.

The influence of shade in decreasing the concentration of leucoanthocyanins in leaves has been noticed by Hillis \& Swain (1957) and by Holden (1957), and the results of my experiments suggest that the synthesis of tannis in raspberry is also affected by light. If this is a general phenomenon then shading seems worth trying as a means of decreasing the concentration of tannin in plants whose leaves contain large amounts. Since the tannin content of leaves seems to increase during the growing season, young leaves in spring may be the best sources of virus. That leaf extracts from closely related species may differ greatly in tannin content, as for example do plum and peach, suggests that many viruses may prove sap-transmissible after being transferred, by grafting, to related plants whose leaves are relatively tannin-free.

Although alumina removes some and nicotine appears to remove most of the tannin from raspberry leaf extracts, extracts from leaves containing raspberry ring spot or beet ring spot viruses made with buffer solution at $\mathrm{pH} 8$ were as infective as those made with the aid of alumina or nicotine. This is probably because weak solutions of nicotine are strongly alkaline ( $\mathrm{pH}$ 9-10) and mixing alumina with weakly acid preparations raises their $\mathrm{pH}$ value above neutrality. Thus both substances maintain the $\mathrm{pH}$ value of leaf extracts to a value where the union of raspberry tannin with these viruses is prevented. Macerating virus- 
infected leaves in alkaline solutions may therefore be a simple way of increasing the infectivity of extracts from plants containing tannins whose inhibitory action is sensitive to $\mathrm{pH}$ values around neutrality.

The results of the serological tests show that extracts made from raspberry leaves with the aid of nicotine are relatively tannin-free and contain protein. Those from leaves infected with beet ring spot virus contained enough virus to be detectable by the precipitation test, suggesting that they may be used successfully for the preparation of antisera to this virus with or without preliminary concentration of the virus by high-speed centrifugation, or precipitation with acetone or ammonium sulphate. These findings probably hold for other sap-transmissible viruses which attain relatively high concentrations in raspberry and perhaps for similar viruses in other tannin-containing plants. Although numerous attempts to transmit aphid-borne viruses mechanically from raspberry to herbaceous test plants all failed, the preparations used may in fact have contained virus which could have been concentrated by highspeed centrifugation and used in attempts to prepare antisera to such viruses.

Little is known of the functions of tannins in plants; the popular belief that they protect plants against invasion by pathogens receives little support from work with plant viruses. It is true that inhibitor is released in detectable amounts when raspberry leaves are rubbed with water and that beet ring spot virus is readily transmissible by mechanical inoculation of infective tobacco sap to peach, a plant which seems free from tannin but not to raspberry, which contains much (Cadman, unpublished). But the presence of tannins in roots and leaves seems to confer no protection on raspberry or strawberry plants against infection by viruses which are transmitted either by insect vectors or through the soil.

Besides those mentioned in the text, I am indebted to Dr E. C. Bate-Smith of the Low Temperature Research Station, Cambridge, and Dr T. White of the Forestal Land, Timber \& Railways Co., Harpenden, for many helpful suggestions, and my colleague Mr P. A. Thompson for making the chromatograms.

\section{REFERENCES}

Bawden, F. C. (1956). Inhibitors and plant viruses. Advanc. Virus Res. $2,32$.

Bawden, F. C. \& KLeczkowski, A. (1945). Protein precipitation and virus inactivation by extracts of strawberry plants. J. Pomol. 21, 2.

Cadman, C. H. (1956). Studies on the etiology and mode of spread of Scottish raspberry leaf-curl disease. J. hort. Sci. 31, 111.

Cadman, C. H. (1958). A ring necrosis virus of potato. Proc. 3rd Conference on potato virus diseases, Wageningen, $\mathrm{p.} 168$.

Craig, L. C. (1944). Identification of small amounts of organic compounds by distribution studies. II. Separation by counter-current distribution. J. biol. Chem. 155, 519.

Gustavson, K. H. (1949). Some protein-chemical aspects of tanning processes. Advanc. Prot. Chem. 5, 354.

Harrison, B. D. (1956). Soil transmission of Scottish raspberry leaf-curl disease. Nature, Lond. 178, 553.

Harrison, B. D. (1957). Studies on the host range, properties and mode of transmission of beet ring spot virus. Ann. appl. Biol. 45, 462. 
Harrison, B. D. (1958). Raspberry yellow dwarf-a solid-born virus. Ann. appl. Biol. 46, 221.

Harrison, B. D. (1959). Further studies on raspberry ring spot and tomato black ring, soil-borne viruses that affect raspberry. Ann. appl. Biol. (in the Press).

Hathway, D. E. (1958a). An approach to the study of vegetable tannins by the oxidation of plant phenolics. J. Soc. Leath. Tr. Chem. 42, 108.

Hathway, D. E. $(1958 b)$. Oak-bark tannins. Biochem. J. 70, 34.

Hrulis, W. E. \& Swain, T. (1957). Influence of illumination on the synthesis of leuco-anthocyanins in leaves. Nature, Lond. 179, 586.

Hirth, L. (1951). Contribution à l'étude de l'inhibition du virus de la mosaĩque du tabac par diverses substances tanniques. Ann. Inst. Pasteur, 80, 458.

HoLDEN, M. (1957). An investigation on polyphenolic compounds of the cacao leaf in connexion with a chemical method for detecting virus infection. J. Sci. Fd Agric. No. 10, 553.

Kassanis, B. \& Kleczkowski, A. (1948). The isolation and some properties of a virus-inhibiting protein from Phytolacca esculenta. J. gen. Microbiol. 2, 143.

McNaIr, J. B. (1930). Gum, tannin and resin in relation to specificity, environment and function. Amer. J. Bot. 17, 187.

ReID, W. W. (1956). The polyphenols and polyphenolase of tobacco, in Chemistry of Vegetable Tannins. Symp. Soc. Leath. Tr. Chem. p. 75.

Thornberry, H. H. (1935). Effect of tannic acid on the infectivity of tobacco mosaic virus. Phytopathology, 25, 931.

Thresh, J. M. (1956). Some effects of tannic acid and of leaf extracts which contain tannins on the infectivity of tobacco mosaic and tobacco necrosis viruses. Ann. appl. Biol. 44, 608.

White, T. (1956). The chemical principles of vegetable tannage. J. Soc. Leath. Tr. Chem. 40, 78.

White, T. (1957). Tannins-their occurrence and significance. J. Sci. Fd Agric. No. 7,377 .

White, T., Kraby, K. S. \& Knowles, E. (1952). Tannins. IV. The complexity of tannin extract composition. J. Soc. Leath. Tr. Chem. 36, 148.

(Received 18 July 1958) 